\title{
Productivity Analysis and Measuring the Returns to Scale of Manufacturing Firms in the South-West Region of Bangladesh
}

\author{
Md.Sajib Hossian', AKM Nazrul Islam² \\ 1 BSS (Hons) in Economics, Khulna University, Bangladesh) \\ 2 (Associate Professor of Environmental Economics, \\ Dhaka School of Economics, Dhaka, Bangladesh) \\ (Constituent Institution of the University of Dhaka)
}

\begin{abstract}
This study considers the leading manufacturing firms of the South-West Region ${ }^{l}$ of Bangladesh. It applies the Cobb- Douglas production function to measure input-output relationship, marginal productivity, allocative efficiency and returns to scale. It finds that among the available firms, cement, jute, and textile manufacturing firms are in decreasing returns to scale whereas fertilizers and seafood processing firms are enjoying increasing returns to scale. The estimated value of marginal productivity and allocative efficiency reveal that labour productivity of all sorts of manufacturing firms has greater than that of capital productivity. It indicates that if firms invest in labour-intensive techniques, they can expect a positive return on investment. This paper also attempts to explore the best techniques for achieving allocative efficiency in the production process of these firms and also identifies the problems facing by the manufacturers of the region.
\end{abstract}

Keywords: manufacturing firms, Cobb-Douglas production function, returns to scale, marginal productivity, allocative efficiency.

\section{Introduction}

Manufacturing firms are the critical component of the economic growth of any country. In Bangladesh, the contribution of the manufacturing industry is increasing day by day, as it is a key player in the field of employment creation, income generation, women empowerment and poverty reduction. Bangladesh has many positive things that may help in its industrial development like the abundance of cheap labour, a huge consumer group, easy access to input and output market, cheap transportation mode, better investment climate etc. But in reality, Bangladesh has abundant underutilized labour forces and side by side lack of investment capital. Due to these underutilized working forces and lack of investment capital, it faces difficulties in achieving accelerated growth in manufacturing sector, although the things are gradually changing. Considering these aspects, identification and proper application of the appropriate techniques have become a burning question for Bangladesh. This paper is an attempt to figure out an appropriate technique for the manufacturing firms of the South-West Region of Bangladesh which would be effective and efficient. It presents productivity analysis and measuring returns to scale for this purpose.

\section{Objectives of the Study}

Keeping in mind the importance of the study of input productivity and profitability in the manufacturing firms in the South-west region of Bangladesh, the objectives of the study have been set out as follows:

i. To identify the input productivity of different categories of manufacturing firms that affect competitive advantage, profitability and growth potential;

ii. To identify the problems associated with manufacturing firms; and

iii. To suggest some policies for the betterment of these firms on the basis of the findings.

\footnotetext{
${ }^{1}$ South-West Region lies in the Khulna Division of Bangladesh. It consists of Khulna, Jessore, Bagerhat, and Satkhira Districts. However, the study considers Khulna, Jessore, and Bagerhat districts as the leading Manufacturing firms in this region are mostly concentrated in these three districts.
} 


\section{Literature Review}

Some studies have been carried out to illustrate the functional relationship between the inputs and outputs and measures technical, economic and allocative efficiency with an aim to enhancing productivity and reducing the cost of production.

Haider and Hasan (2010) observe the manufacturing firms of the south-west region of Bangladesh have some blessing features in terms of product, input sources, location, factor market, firm size etc.

Dwett (2003-2004) has defined that marginal productivity is the additional output that can be produced by employing one more unit of the input while holding other inputs constant.

Hagendorf (2009) who describes Cobb-Douglas Production function is the only production function which has the property of a constant functional distribution of income of the factors of production and the estimation of the parameters of an aggregate production function is central to work on growth, technological change, productivity, and labour.

Hussain (1991) estimates the production function for measuring the degree of returns to scale in Peshawar valley. Although Sindh province has a different structure of agriculture as compared with other provinces, the study shows that the production of onion, tomato and chillies exhibit constant returns to scale. These results indicate that output would increase by the same proportion if all inputs are increased proportionally.

Hossain (1987) notices that industries in Bangladesh have potential allocative efficiency as they are using at least some capital. By estimating the marginal productivity of labour and capital, he explains that allocative efficiency would achievable through appropriate pricing of capital and its proper disbursement among the proprietorships.

Banda and Verdugo (2007) have studied the issue of labour productivity between 14 groups and 205 activity classes that contribute to 5.3 percent and 2.3 percent to the observed growth at each aggregation level respectively. In the case of aggregate output growth, multi-factor productivity helps explain between 58 percent and 69 percent; while it accounts for 62 percent of aggregate labour productivity growth. High productivity has acclaimed as a sure means of boosting economic growth and raising the standards of living of the people.

Bhujel and Ghimari (2006) use the Cobb-Douglas production function to estimate the production function for Boro rice. In this model, the coefficient of winter rice is positive and significant at a 1 percent level which exhibited that, other factors remain constant; a 1 percent increase in the area would lead to a 0.91 percent increase in winter rice production. Again, other factors remain constant; a 1 percent increase in phosphorous, potash and tractor used would result into 0.33 percent, 0.02 percent, and 0.02 percent increase in production respectively from the use of respective variables.

Kehinde and awoyemi (2009) deal with the issue of improving economic efficiency in sawn wood in Ondo and Osun states, south-west Nigeria. The stochastic frontier approach is used to estimate a self-dual Cobb-Douglas production function which gives an estimation of technical, allocative and economic efficiencies. They observed, on average sawmills in Ondo and Osun states have high technical, allocative and economic efficiencies. In both states, sawmills have the potentiality to either increase output using the same level of input or to reduce the present level of input use for the same level output.

Ali et al. (2009) find that the growth in output and productivity is largely driven by the incremental use of input doses. They estimate average technical efficiency score is 0.902 under a variable return to scale model with an average scale efficiency score of 0.870 . They claim the positive gain in TFP is basically due to change in technological progress i.e. shifted in production frontier due to increased of capital input.

Ahmed (2007) observes the export of seafood items have been gradually increasing during the last 36 years. Currently, Bangladesh produces 2.6 percent of the total production of shrimp in the world market. He has identified several factors, such as an easy entrance in the European and U.S market, availability of cheap labour is one of them. 
Kibria and Tisdell (1983) observe that the labour intensity of weaving trends to decline in the jute sector. This trend might be of interest to those who believe that labour-intensive would more appropriate than a capital-intensive technique for the developing countries. Moreover, with the introduction of new technological approach in developing countries like Bangladesh, the share attributable to capital trends to rise in terms of total production.

\section{Materials and Methods}

The study has purposively selected five different types of manufacturing firms, has studied their management and operations, including cement, fertilizers, jute, seafood processing, and textiles and then randomly taken six sample sizes from each different manufacturing firms.

Following the conventional survey techniques, the study has collected five years' (2006-2010) data on the total value of production, labour cost and capital cost and other relevant information by directly asking the firms' relevant management persons through using a structured questionnaire.

Some secondary information is also obtained from research journals, books, reports on the related study for studying relevant existing literature, developing an analytical framework and identifying firms' location, etc. In the study, the present value of the capital investment and the working capital is used as the capital input, and the paid-up wages and benefits have been used as labour input.

\subsection{Analytical Framework}

Cobb-Douglas production function has been considered as an appropriate due to the simplicity, widespread usage in empirical literature, bluntness in estimating returns to scale, marginal productivity, and allocative efficiency. The authors use simple mathematical and statistical tools such as Ordinary Least Square method for the estimation. It is also assumed that perfect competition prevails both in the factor market and product market.

Two undependable variables, namely labour cost and capital cost have taken into account, which is likely to have an impact on production of firms. However, all variables are expressed in monetary terms.

In this study, a nonlinear relationship of Cobb-Douglas production function has converted into linear ones with appropriate transforms so that work could be done within the frame of the classical regression model. Here, this transformation has been demonstrated by taking up a multivariable extension of the two variable log-linear models. In economics, Cobb-Douglas functional form of the production function is widely used to present input-output relationship. It was proposed by Knut Wicksell (1851-1926) and tested against statistical evidence by Charles Cobb and Paul Douglas in 1900-1928.

For production:

$\mathrm{Y}=$ total production (the monetary value of all goods produced in a year),

$$
\mathrm{Y}=\mathrm{AL}^{\alpha} \mathrm{K}^{\beta}
$$

$\mathrm{L}=$ labour input, $\mathrm{K}=$ capital input, $\mathrm{A}=$ total factor productivity or is an efficiency parameter reflecting the level of technology.

$\alpha$ and $\beta$ are the output elasticities of labour and capital, respectively these values are constants determined by available technology.

Output elasticity measures the responsiveness of output change in levels of either labour or capital used in production. For example, if $\alpha=0.15$, a 1 percent increase in labour would lead to an approximately 0.15 percent increase in output. Further, if $\alpha+\beta=1$, the production function has a constant return to scale. If $\alpha+\beta<1$, returns to scale are decreasing, and if $\alpha+\beta>1$, returns to scale are increasing. Assuming, perfect competition, $\alpha$ and $\beta$ can be shown to be labour and capital's share of output. According to Gujarati (2008), the Cobb-Douglas

production function in stochastic form may be written as $\quad \mathrm{Y}=\beta_{1} L_{2 i}^{\beta_{2}} K_{3 i}^{\beta_{3}} e^{u_{i}}$

Where, $\mathrm{Y}=$ Output; $\mathrm{L}=$ Labor input; $\mathrm{K}=$ Capital input

$\mathrm{u}=$ Stochastic disturbance

$\mathrm{e}=$ Base of the natural logarithm

From the equation, it is clear that the relationship between output and the two inputs is non-linear. However, transforming this model using logarithm and obtain,

$\operatorname{In} Y_{i}=\ln \beta_{1}+\beta_{2} \operatorname{In} L_{2 i}+\beta_{3} \ln K_{3 I}+u_{i}$

$\operatorname{In} Y_{i}=\beta_{0}+\beta_{2} \ln L_{i}+\beta_{3} \ln K_{i}+u_{i}$ 
Where, $\beta_{0}=\ln \beta_{1}$. Thus, the model is linear in parameters $\beta_{0}, \beta_{2}$ and $\beta_{3}$ and is therefore, a linear regression model. In a short, it is a $\log$-linear model. According to equation, (1) $\alpha=\beta_{2}$ and $\beta=\beta_{3}$.

\subsection{Hypothesis Test}

Production does not highly depend on labour input.

and the alternative hypothesis is: Production highly depends on labour input.

To prove these hypotheses it is essential to use the t-test to test a hypothesis about any individual partial regression coefficient. Now here it is considered labour input coefficient.

Now assuming,

$$
\begin{gathered}
H_{O}: \beta_{2}=0 \text { and } \\
H_{0}: \beta_{2} \neq 0
\end{gathered}
$$

The null hypothesis states that with $\mathrm{K}$ (capital) holding constant, L (labour) has no impact on Y (output). And the alternative hypothesis states that holding $\mathrm{K}$ constant $\mathrm{L}$ has a significant impact on $\mathrm{Y}$.

Here, $t$ ratio for each $\hat{\beta}_{\mathrm{i}}$ has been computed.

\subsection{Marginal productivity of Labour and Capital}

$$
t^{*}=\frac{\hat{\beta}_{i}}{s_{\widehat{\beta}_{i}}}
$$

The study measures the Marginal productivity of labour and capital by taking partial derivation of Cobb- Douglas production function:

Marginal Productivity of labour, $M P_{L}=\frac{d Y}{d L}=\beta_{2} \cdot \beta_{0} \cdot K^{\beta_{3}} \cdot L^{\beta_{2-1}}$

Where, $\beta_{2}=$ Coefficient of Labor; $\beta_{0}=$ Coefficient of intercept term;

$\beta_{3}=$ Coefficient of Capital; $\mathrm{K}=$ Average Capital $\operatorname{cost} ; \mathrm{L}=$ Average Labor wage

Marginal productivity of labor, $\mathrm{MP}_{\mathrm{K}}=\frac{\mathrm{dY}}{\mathrm{dK}}=\beta_{3} \cdot \beta_{0} \cdot \mathrm{K}^{\beta_{3-1}} \cdot \mathrm{L}^{\beta_{2}}$

Where, $\beta_{3}=$ Coefficient of Capital; $\beta_{0}=$ Coefficient of intercept term

$\beta_{2}=$ Coefficient of Labor; $K=$ Average Capital cost $\mathrm{L}=$ Average Labor wage

Marginal rate of technical substitution, $M R T S_{L K}=\frac{M P_{L}}{M P_{K}}$

And comparing the marginal productivity of labour and capital the allocative efficiency of a firm can be measured.

\section{Data Analysis and Interpretation}

Here, the study estimates the production functions of the five manufacturing firms. In which, labour input is measured from paid wages and the capital is measured from the monetary value of the fixed asset like buildings and machinery and working capital costs like maintenance and energy cost.

The simple log linear regression model is:

$\ln Y_{i}=\beta_{0}+\beta_{2} \ln L_{i}+\beta_{3} \ln K_{i}+$ ?

The estimated results that have been derived on the basis of the estimated value of the relevant

\begin{tabular}{|c|c|c|c|c|c|c|}
\hline $\begin{array}{c}\text { Types of } \\
\text { Firms }\end{array}$ & & $\beta_{0}$ & $\beta_{2}$ & $\beta_{3}$ & $\mathbf{R}^{2}$ & F \\
\hline \multirow[b]{2}{*}{ Cement } & $\beta$ & 4.281 & 0.667 & 0.09 & \multirow[t]{2}{*}{0.927} & \multirow[t]{2}{*}{172.371} \\
\hline & $\mathbf{t}$ & 11.870 & 8.70 & 0.731 & & \\
\hline \multirow[b]{2}{*}{ Fertilizers } & $\beta$ & 4.660 & 0.878 & 0.176 & \multirow[t]{2}{*}{0.917} & \multirow[t]{2}{*}{149.820} \\
\hline & $\mathrm{t}$ & 21.373 & 9.714 & 2.052 & & \\
\hline \multirow[b]{2}{*}{ Jute } & $\beta$ & 4.679 & 0.873 & -0.003 & \multirow[t]{2}{*}{0.899} & \multirow[t]{2}{*}{119.828} \\
\hline & $t$ & 7.518 & 4.666 & -0.020 & & \\
\hline \multirow{2}{*}{$\begin{array}{l}\text { Sea Food } \\
\text { Processing }\end{array}$} & $\beta$ & 4.428 & 0.892 & 0.207 & \multirow[t]{2}{*}{0.928} & \multirow[t]{2}{*}{172.879} \\
\hline & $\mathbf{t}$ & 16.138 & 9.232 & 1.293 & & \\
\hline \multirow[t]{2}{*}{ Textiles } & $\boldsymbol{\beta}$ & 3.324 & 0.281 & 0.591 & \multirow[t]{2}{*}{0.851} & \multirow[t]{2}{*}{76.996} \\
\hline & $t$ & 8.256 & 3.100 & 5.111 & & \\
\hline
\end{tabular}
variables are shown in Table 1 below

Table 1: Estimation of Production Function

Source: Based on Field Survey, 2011

All the value of $\mathbf{t}$ in the table are significant at $5 \%$ level 


\subsection{1: Cement Manufacturing Firms}

From the table 1, it is seen that the output elasticities of labour and capital are 0.667 and 0.09 respectively for cement manufacturing firms over the study period. That means, holding the capital input constant, a 1 percent increase in labour input would lead to an average of about 0.667 percent increase in production output. Similarly, holding the capital input constant, a 1 percent increase in capital input would lead to an average of about 0.09 percent increase in production output. The value of $\mathrm{R}^{2}$ for these firms is 0.927 , which reveals that 92.7 percent of the total variation of Y (output) is explained by L (labour) and K (capital).

\subsection{2: Fertilizer Manufacturing Firms}

From the table 1, it is also seen that in case of fertilizer manufacturing firms over the study period 2006-2010 holding capital input constant, a 1 percent increase in labour input would cause to an average about 0.878 percent increase in the output (Y) side by side when labour input is held constant, a 1 percent increase in capital input would cause an average decrease in output by 0.176 . The value of $\mathrm{R}^{2}$ for these firms is 0.917 , which depicts that 0.917 percent of the total variation of the output is explained by the explanatory variables i.e. labour and capital.

\subsection{3: Jute Manufacturing Firms}

Over the study period (2006-2010) the output elasticities of capital and labour for Jute manufacturing

Firms are 0.873 and- 0.003 respectively. It can be described as when the capital input is constant, a 1 percent increase in labour input leads to an average of about 0.873 percent increase in the output but a 1 percent increase in capital input, holding labour input constant would lead to an average of -0.003 percent decrease in the output. With the reference to table 1 , the value of $\mathrm{R}^{2}$ for these firms is 0.899 , which depicts that 0.899 percent of the total variation in $\mathrm{Y}$ is explained by explanatory variables (labour and capital).

\subsection{4: Seafood Processing Firms}

From the table1, it is also seen that in the case of seafood manufacturing Firms over the study period 2006 2010 holding capital input constant, a 1 percent increase in labour input leads to an average of about 0.892 percent increase in the output $(\mathrm{Y})$ side by side when labour input is held constant, a 1 percent increase in capital input would lead to an average increase in output by 0.207 percent. The value of $R^{2}$ for these firms is 0.928 , which depicts that 0.928 percent of the total variation of the output is explained by the explanatory variables i.e. labour and capital.

\subsubsection{Textile Manufacturing Firms}

Lastly, from the table 1, in the case of textiles manufacturing firms over the study period $2006-2010$, it is seen that holding capital input constant, a 1 percent increase in labour input would cause to an average around 0.281 percent increase in output, whereas holding labour constant, a 1 percent increase in capital input would cause to an average increase in output by around 0.6 percent. For these firms, the value of $R^{2}$ is 0.851 , which 0.851 percent of the total variation in output is explained by the inputs labour and capital.

\section{Marginal Productivity of Labour and Capital and Allocative Efficiency}

The marginal productivity of labour is the increase in output resulting from an incremental increase in the amount of labour employed whereas marginal productivity of capital is the increase in output that results from an increase in the amount of capital employed. The authors have treated marginal productivity of labour is the increase in output resulting from an increase in the amount of labour wage and the marginal productivity of capital is the increase in output that results from an increase in the amount of capital cost. Again, a comparison of marginal productivity of labour and capital from the production function can provide a useful insight into their allocative efficiency. 
6.1 Estimation of Allocative Efficiency

The study calculates the allocative efficiency of sample manufacturing firms by comparing their respective marginal productivity of labour and capital with respect to investment in labour and capital.

The marginal productivity of labour and capital is presented in below table 2

Table 2: Marginal Productivity of labour and capital for different firms

\begin{tabular}{|c|c|c|c|}
\hline Firms & $\mathbf{M P}_{\mathbf{L}}$ & $\mathbf{M P}_{\mathbf{K}}$ & MRST $_{\mathbf{L k}}$ \\
\hline Cement & 4.43 & 0.025 & 177.2 \\
\hline Fertilizer & 6.19 & 0.089 & 69.55 \\
\hline Jute & 4.26 & -0.00041 & -10390 \\
\hline Sea Foods & 5.62 & 0.205 & 27.41 \\
\hline Textile & 11.1 & 0.52 & 21.4 \\
\hline
\end{tabular}

Source: Based on Field Survey, 2011

\subsection{1: Cement Manufacturing Firms}

From the table 2, in the case of cement manufacturing firms, the estimated $\mathrm{MP}_{\mathrm{L}}$ is Tk. 4.43. and $\mathrm{Tk} \mathrm{MP}_{\mathrm{K}}$ is 0.025 for Tk. 1 of investment which implies that if one additional Tk. is invested for labour the return will be equal to Tk. 4.43 whereas if $100 \mathrm{Tk}$. is invested for capital the return will be equal to only Tk.2.5. The MRTS LK $_{\text {. }}$ is equal to Tk. 177.2 that indicates if the firm wants to remain on the same production level or same isoquant, it can sacrifice capital of Tk.177.2 for Tk.1 an additional investment in labour. Thus, the firm can reduce its production cost for the present level of output by utilizing labour- intensive technique.

\subsection{2: Fertilizer Manufacturing Firms}

Similarly, for fertilizer manufacturing firms from the table 2, the estimated $\mathrm{MP}_{\mathrm{L}}$ and $\mathrm{MP}_{\mathrm{K}}$ are 6.19 and 0.089 respectively for the investment of Tk.1. It means that when a 1 additional Tk. will be invested for labour the return will be equal to Tk. 6.19. Again, in the case of capital, if Tk.100 is invested for capital the return will be equal to only Tk. 8.9. The MRTS ${ }_{\text {LK }}$ is Tk.69.55 that implies if the firms want to remain at the same production level it can withdraw capital of Tk. 69.55 for an additional investment of Tk. 1 in labour. And in this way, the firms can reduce its production cost for the present level of output by utilizing labour- intensive technique. That also ensures the efficiency of resource allocation.

\subsection{3: Jute Manufacturing Firms}

And, for Jute manufacturing firms, $\mathrm{MP}_{\mathrm{L}}$ is greater than $\mathrm{MP}_{\mathrm{K}}$, which 4.26 and -0.00041 respectively. In this respect, increase investment in labour-intensive technique can ensure allocative efficiency. In contrast, $\mathrm{MP}_{\mathrm{k}}$ shows a negative return for additional investment in capital. In this model, the slope of isoquant, MRTS ${ }_{\text {LK }}$ is equal to Tk. -10390 which represents if the firms want to remain on the same production level or same isoquant they will have to substitute capital of Tk.10390 for an additional investment of Tk. 1 in labour. By doing this, firms can reduce the production cost for the same level of output and ensure the efficient resource allocation.

\subsection{4: Sea Foods Processing Firms}

In the case of Seafood manufacturing firms, the estimated $\mathrm{MP}_{\mathrm{L}}$ and $\mathrm{MP}_{\mathrm{K}}$ are 5.62 and 0.205 for the investment of Tk. 1. It represents that if Tk.1 is invested for the labour the return will be equal to Tk. 5.62 whereas if Tk.100 is invested for the capital that will return only Tk. 20.5. For these firms, MRTS ${ }_{\text {LK }}$ is equal to 27.41, which exhibits that these firms can substitute capital of Tk. 27.41 for an additional investment in labour by Tk.1 to remain on the same production level. So, it will be better for these firms shifting investment from capital-intensive technique to labour- intensive technique.

\subsection{5: Textile Manufacturing Firms}

Lastly, for textile manufacturing firms, from the table 2, it is seen that $\mathrm{MP}_{\mathrm{L}}$ and $\mathrm{MP}_{\mathrm{K}}$ are 11.1 and 0.52 respectively for Tk. 1 investment. It implies that when additional Tk. 1 will be invested for labour the return will be equal to Tk. 11.14. Again, in the case of capital, it is found that if Tk.100 is invested for the capital that will return only Tk. 52. For these firms, MRTS ${ }_{\mathrm{LK}}$ is equal to 21.4, which represents that these firms can sacrifice capital of Tk. 21.4 for an additional investment in labour by Tk.1 to remain on the same production level. Therefore, it is better for these firms shifting investment from capital-intensive technique to labour-intensive technique as increase investment in labour-intensive technique will ensure allocative efficiency. 


\section{Measurement of Returns to Scale}

In economics, returns to scale arise in the context of a firm's production function. It refers to changes in output resulting from a proportional change in all inputs (where all inputs increase by a constant factor). If output increases by that same proportional change then there are constant returns to scale. If output increases by less than that proportional change, there is decreasing returns to scale. If output increases by more than that proportional change then there is increasing returns to scale.

Where, $\beta_{2}+\beta_{3} \neq 1$, shows the presence of increasing or decreasing returns to scale;

$\beta_{2}+\beta_{3}>1$, shows increasing returns to scale; and

$\beta_{2}+\beta_{3}<1$, shows decreasing returns to scale.

Table 3: Estimation of Returns to Scale

\begin{tabular}{|c|c|c|}
\hline \multirow{2}{*}{ Types of Firms } & The coefficient of labour and & \multirow{2}{*}{ Returns to Scale } \\
\cline { 2 - 3 } & $\boldsymbol{\beta}_{\mathbf{2}}+\boldsymbol{\beta}_{\mathbf{3}}$ & \multirow{2}{*}{ Decreasing } \\
\hline Cement Manufacturing Firms & $0.667+0.09=0.757$ & Increasing \\
\hline Fertilizer Manufacturing Firms & $0.878+0.176=1.054$ & Decreasing \\
\hline Jute Manufacturing Firms & $0.873-0.003=0.87$ & Increasing \\
\hline Sea Foods Manufacturing Firms & $0.892+0.207=1.099=1.1$ & Decreasing \\
\hline Textile manufacturing Firms & $0.281+0.591=0.872$ & \\
\hline
\end{tabular}

Source: Based on Field Survey, 2011

From the table 3, it is seen that that firms like fertilizer and seafood processing are in increasing returns to scale that implies 1percent increase inputs will to lead to an increase of output by more than one percent. Whereas cement, jute and textile are in decreasing returns to scale so any increases in inputs (both labour and capital) would lead to an increase in output less than one percent.

\section{Hypothesis Test Results}

But It is observed from the Table 4 that in case of above mentioned all sorts of firms, the computed t value $\left(t^{*}\right)$ for the labour coefficient is greater than the tabulated t value at $5 \%$ level of significance so, the null hypothesis is rejected, implying that labour has a significant impact on their output

Table 4: Table and the computed value of $t$ (for labour coefficient, $\beta_{2}$ )

\begin{tabular}{|c|c|c|c|}
\hline & & Computed t* value & Status of hypothesis \\
\hline Cement & 2.052 & 8.70 & The null hypothesis is rejected \\
\hline Fertilizer & 2.052 & 9.714 & The null hypothesis is rejected \\
\hline Jute & 2.052 & 4.666 & The null hypothesis is rejected \\
\hline Textiles & 2.052 & 9.232 & The null hypothesis is rejected \\
\hline Seafood processing & 2.052 & 3.100 & The null hypothesis is rejected \\
\hline
\end{tabular}

Source: Based on Field Survey, 2011

\section{IX: $\quad$ Findings}

The major findings of the study are as follows:

Firstly, estimation of marginal returns to scale shows that manufacturing firms like fertilizer and seafood are in increasing returns to scale. Whilst cement, jute and textile are in decreasing returns to scale which implies that production would not increase at the same proportion even if the inputs (capital and labour) were increased proportionately.

Secondly, the marginal productivity of labour is shown to be greater than that of marginal productivity of capital.

Thirdly, in spite of increased investment in capital inputs, the production processes of manufacturing firms of this region remain manual or semi-automated primarily due to the supply of unskilled and cheap labour coupled with backdated machinery that incurs high operating costs. Besides these, from the survey, it is found that shortage of raw materials, high-interest rates, and high energy costs also contribute to the low productivity of all these manufacturing firms, and these factors lead to make the allocation of capitalintensive techniques inefficient. 


\section{Concluding Remarks}

Manufacturing firms in the South-West region are acting as a vital player in employment generation, women empowerment and thereby reducing poverty but manufacturing firms in this region are mostly characterized by underutilization of equipment, lack of skill labours, shortage of raw materials and lack of investment finance. Since the study finds that the marginal productivity of labour is higher than that of capital. Therefore, firms may shift most of their resources from capital-intensive to labour-intensive a technique to maintain the current level of production at minimum production cost, and thus they can ensure efficient resource allocation. But for the higher productivity and profitability of these firms, the backdated machinery should be replaced with modern and economic efficient ones, and skills labour should also be employed.

Considering the huge potential of these firms in terms of the socio-economic development of this region, the Government of Bangladesh should come forward to deal with the problems faced by them. In this regard, the government should ensure timely availability of raw materials, duty-free import of the hightech machinery, uninterrupted supply of power and energy at low costs, bank loan at low costs, and also make arrangement for workforce's skill development activities. And those initiatives will help to boost these firms and make them able to contribute to the economy of this region.

\section{REFERENCES}

[1] ALI, J. SING, S.P. and EKANEM, E. (2009). Efficiency and Productivity Changes in Indian Food Processing Industry: Determinants and Policy. Journal of International Food and Agribusiness Management Review, 12 (1), pp.43-66.

[2] BANDA, HS. and VERDUGO, L. (2007). Multifactor Productivity and its Determinants: An Empirical Analysis for Mexican Manufacturing’ Banco de Mexico. Working Paper, No. 2007-09, pp.9-11.

[3] BHUJEL, R.B. and GHIMIRE, S.P. (2006). Estimation of Production Function of Hiunde (Boro) Rice. Nepal Agric. Res. Journal, 7, pp.88-97.

[4] C O B B , C.W. and Douglas, P.H. (1928). A theory of production. The American Economic Review, 18(1), pp. 139-165.

[5] DEWETT, K.K. and CHAND, A (2003- 2004). Production possibility curve and production function, Modern Economic Published Theory (ME). 21 Rev.ed., Shaymal Charitable Trust- 110055, New Delhi, pp. 125-130

[6] GUJARATI, DAMODAR, N. (2003).Multiple Regression Analysis: "The problem of Estimation"' In Basic Econometrics .4th edition, New York: McGraw-Hill Inc, pp. 202- 247.

[7] HAIDAR, M.Z. and HASAN, K.M. (2010). Investment climate in the south-west region of Bangladesh: A study of the manufacturing sector, working paper 4/ 2000, Investment Climate Series: Economic Research Group.

[8] HOSSAIN, S.I.(1987). Allocative and technical efficiency: A study of rural enterprises in Bangladesh. The Developing Economies, 25(1), pp.55-72.

[9] HUSSAIN, A. (1991). Resource Use, Efficiency, and Returns to Scale: A Case S t u d y o f the Peshawar Valley' (Staff Paper). Department of Agricultural and Applied Economics, University of Minnesota, Twin Cities. pp. 91-29.

[10] KEHINDI, A.L. and T.T. AWOYEM. (2009) Analysis of Economics Efficiency in Sawn wood Production in Southwest Nigeria. Journal of Human Ecology, 26(3), pp. 175-183.

[11] KIBRIA, M.G. and TISDELL, C.A. (1983).An Analysis of Technological Change in Jute Weaving in Bangladesh, 1954/55 to 1979/80. The Developing Economies, 21(2), pp.151-159.

[12] SAMUELSON,A.PAUL (1979). Douglas's Measurement of Production Functions and Marginal Productivities, Journal of Political Economy, pp. 923-39. 


\section{Appendix}

Appendix A: Production input-output Data and Marginal Productivity of Production Process of Manufacturing Firms

Appendix A1: Monetary value of production, Y (Values in Crore Tk.)

\begin{tabular}{|c|r|r|r|r|r|r|r|r|}
\hline \multirow{2}{*}{$\begin{array}{c}\text { Types of } \\
\text { Firms }\end{array}$} & \multicolumn{4}{|c|}{ Year } & $\begin{array}{c}\text { Number of } \\
\text { observation } \\
\text { N }\end{array}$ & $\begin{array}{c}\text { Total } \\
\text { Production } \\
\text { over 2006- } \\
\text { 2010) }\end{array}$ & $\begin{array}{c}\text { Average } \\
\text { Production }\end{array}$ \\
\hline Cement & 314 & 322.4 & 363.23 & 360.1 & 386.67 & 30 & 1746.4 & 58.21 \\
\hline Fertilizers & 303.84 & 352.97 & 404.242 & 419.076 & 449.62 & 30 & 1929.748 & 64.325 \\
\hline Jute & 423.09 & 432.245 & 486.06 & 447.034 & 487.18 & 30 & 2275.609 & 75.85 \\
\hline $\begin{array}{c}\text { Sea Food } \\
\text { Processing }\end{array}$ & 441.08 & 574.55 & 591.817 & 528.199 & 543.232 & 30 & 2678.878 & 89.29 \\
\hline Textile & 369.46 & 385.44 & 398.5 & 421.54 & 441.638 & 30 & 2016.578 & 67.21 \\
\hline
\end{tabular}

Appendix A2: Labour wages, L (Values in Crore Tk.)

\begin{tabular}{|c|c|c|c|c|c|c|c|c|}
\hline \multirow{2}{*}{$\begin{array}{l}\text { Types of } \\
\text { Firms }\end{array}$} & \multicolumn{5}{|c|}{ Year } & \multirow{2}{*}{$\begin{array}{c}\text { Number of } \\
\text { observation, } \\
\mathbf{N}\end{array}$} & \multirow{2}{*}{$\begin{array}{c}\text { Total } \\
\text { labour } \\
\text { wage } \\
\text { (over 2006- } \\
\text { 2010) }\end{array}$} & \multirow{2}{*}{$\begin{array}{c}\text { Average } \\
\text { labour } \\
\text { wage }\end{array}$} \\
\hline & 2006 & 2007 & 2008 & 2009 & 2010 & & & \\
\hline Cement & 2.88 & 3.045 & 3.125 & 3.218 & 3.3385 & 30 & 15.606 & 0.52 \\
\hline Fertilizers & 1.971 & 2.153 & 2.425 & 2.6135 & 2.86 & 30 & 12.0225 & 0.40 \\
\hline Jute & 3.712 & 3.723 & 4.086 & 4.236 & 4.37 & 30 & 20.127 & 0.67 \\
\hline $\begin{array}{c}\text { Sea Food } \\
\text { Processing }\end{array}$ & 4.0102 & 4.648 & 4.6878 & 4.392 & 4.5561 & 30 & 22.294 & 0.74 \\
\hline Textile & 0.9905 & 1.0142 & 1.0132 & 1.0795 & 1.1384 & 30 & 5.23578 & 0.174 \\
\hline
\end{tabular}

Appendix A3: Capital cost, $\mathbf{K}$ (Values in Crore Tk.)

\begin{tabular}{|c|c|c|c|c|c|c|c|c|}
\hline \multirow{2}{*}{$\begin{array}{c}\text { Types of } \\
\text { Firms }\end{array}$} & \multicolumn{5}{|c|}{ Year } & \multirow{2}{*}{$\begin{array}{c}\text { Number of } \\
\text { observation, } \\
\mathbf{N}\end{array}$} & \multirow{2}{*}{$\begin{array}{c}\text { Total } \\
\text { Capital Cost } \\
\text { (over 2006- } \\
\mathbf{2 0 1 0}) \\
\end{array}$} & \multirow{2}{*}{$\begin{array}{c}\text { Average } \\
\text { Capital } \\
\text { cost }\end{array}$} \\
\hline & 2006 & 2007 & 2008 & 2009 & 2010 & & & \\
\hline Cement & 64 & 68.65 & 76.14 & 82.46 & 88.86 & 30 & 380.11 & 12.67 \\
\hline Fertilizer & 30.7 & 33.014 & 34.591 & 35.134 & 36.102 & 30 & 169.541 & 5.56 \\
\hline Jute & 133.51 & 137.67 & 143.74 & 148.217 & 156.716 & 30 & 719.853 & 24 \\
\hline $\begin{array}{c}\text { Sea Food } \\
\text { Processing }\end{array}$ & 24.77 & 26.9 & 29.79 & 29.285 & 30.498 & 30 & 141.243 & 4.7 \\
\hline Textile & 45.85 & 45.897 & 46.2995 & 48.799 & 50.099 & 30 & 236.9445 & 7.90 \\
\hline
\end{tabular}

Note: Tk. indicates the basic monetary unit of Bangladesh. 